Original Article

\title{
Potensi madu pada peningkatan jumlah sel spermatogenik tikus (Rattus norvegicus) yang kekurangan nutrisi
}

\section{Potential of honey in increasing the number of spermatogenic cells of rats (Rattus norvegicus) with nutritional deficiencies}

\author{
Linda Listyorini $^{1 *}$, Tatik Hernawati ${ }^{2}$, Tri Wahyu Suprayogi ${ }^{2}$ \\ ${ }^{1}$ Mahasiswa Magister, \\ ${ }^{2}$ Divisi Reproduksi Veteriner, Fakultas Kedokteran Hewan, Universitas Airlangga \\ * Penulis koresponden, e-mail: lindalistyorini@gmail.com
}

\begin{abstract}
Open access under CC BY - SA license, DOI: 10.20473/ovz.v10i1.2021.12-17
Received January 26 2021, Revised February 8 2021, Accepted February 102021

Published online April 12021
\end{abstract}

\begin{abstract}
This study aimed to determine honey's potential in increasing the number of spermatogenic cells (spermatogonium, spermatocyte and spermatid) of rats (Rattus norvegicus) with nutritional deficiencies. Twenty four male rats (Rattus norvegicus) were randomly divided into four groups. Negative control (K-) mice was not fasted nor given honey. Positive control $(\mathrm{K}+)$ mice was fasted for 5 days without the administration of honey. The treatment group rats were fasted for 5 days followed by administration of honey $30 \%(\mathrm{P} 1)$ and $50 \%$ (P2) in drinking water for 10 days. On the 76th day all rats were sacrificed and their testes were collected for histological slides using Hematoxylin-Eosin staining. The results showed that fasting treatment for five days (group $\mathrm{K}+$ ) caused a decrease $(\mathrm{p}$ $<0.05)$ in the number of spermatogonia cells, spermatocytes and spermatids compared to those of the normal mice (group $\mathrm{K}-$ ). Administration of 50\% honey (group P2) for 10 days caused an increase (p $<0.05)$ in the number of spermatogonia cells, spermatocytes and spermatids compared to the $\mathrm{K}+$ group mice. In P2 group, the number of spermatogonia cells was lower ( $p<0.05)$, while the number of spermatocytes and spermatids was not significantly different than in the $\mathrm{K}$ - group mice. It could be concluded that the administration of honey was able to regenerate the testicular tissue of rats with nutritional deficiency by increasing the number of spermatogenic cells in the seminiferous tubules.
\end{abstract}

Keywords: honey, nutritional deficiency, Rattus norvegicus, spermatogenic cells

\section{PENDAHULUAN}

Pada hewan coba kekurangan nutrisi menyebabkan hewan menjadi infertil dikarenakan adanya degenerasi testis (Safitri et $a l .$, 2015). Tikus merupakan salah satu hewan eksperimental yang populer dalam studi fungsi reproduksi. Salah satu keuntungannya adalah memiliki waktu siklus reproduksi yang singkat (Krinke, 2000). Degenerasi jaringan testis dapat menyebabkan rendahnya jumlah spermatozoa yang dihasilkan tubulus seminiferus (Jainudeen dan Hafez, 2013). Kekurangan nutrisi dapat menyebabkan defisiensi imun pada tikus putih jantan. Madu dapat meningkatkan respon imun sehingga dapat memperbaiki jaringan testis dalam meningkatkan produksi sel spermatogenik di tubulus seminiferous.

Standar Nasional Indonesia (SNI) 3545:2013 mendefinisikan madu sebagai cairan alami yang umumnya mempunyai rasa manis yang dihasilkan oleh lebah madu (Apis sp.) dari sari bunga tanaman (floras nectar) atau bagian lain tanaman (SNI, 2013). Madu bersumber dari nektar, yaitu cairan yang mengandung gula, sekresi kelenjar tumbuhan (Sihombing, 2005). 
Nektar dapat memainkan banyak peran, diantaranya menjadi daya tarik penyerbuk dan memediasi interaksi dengan mikroba (AlvarezPérez et al., 2012; Canto dan Herrera, 2012). Nektar mengandung air, gula dan asam amino yang menarik penyerbuk serta melindungi dari nectar robbers dan mikroorganisme yang dilakukan oleh senyawa sekunder dan protein antimikroba (Heil, 2011).

$$
\text { Indonesia memiliki berbagai }
$$

keanekaragaman tumbuhan. Beberapa tanaman yang dapat menghasilkan nektar yaitu kaliandra, randu, rambutan dan lain-lain. Perbedaan sumber nektar akan membuat madu memiliki komposisi, rasa, aroma, maupun penampilan fisik yang berbeda (Bogdanov et al., 2008). Madu mengandung zat antioksidan, merupakan senyawa yang memiliki peranan penting dalam menjaga kesehatan karena dapat menangkap molekul radikal bebas sehingga menghambat reaksi oksidatif dalam tubuh yang merupakan penyebab penyakit (Adawiyah et al., 2015).

Madu memiliki kandungan zat antioksidan yang tinggi, diantaranya flavonoid. Flavonoid dapat merusak membran sel dengan cara menghambat sintesis makromolekul. Flavonoid juga dapat mendepolarisasi membrane sel dan menghambat sistesis DNA, RNA. Selain itu flavonoid juga dapat menghambat sintesis asam nukleat, menghambat fungsi membrane sitoplasma dan menghambat metabolisme energi pada bakteri (Cushnie et al., 2005). Antioksidan dapat menetralisir efek negatif yang ditimbulkan oleh radikal bebas (Umar et al., 2015), mempertahankan struktur membran sel spermatozoa terhadap adanya radikal bebas (Agarwal et al., 2005).

Kondisi kurang nutrisi pada tikus dapat berdampak pada pertumbuhan sel spermatozoa (Toledo et al., 2011), juga dapat mengurangi jumlah sel sertoli (Genovese et al., 2010). Status nutrisi memengaruhi morfofisiologi testis sebagai sistem endokrin. Neuron yang mengontrol pelepasan GnRH sangat sensitif terhadap perubahan status gizi (Caron et al, 2012). Tujuan penelitian ini adalah untuk mengetahui potensi madu pada regenerasi jaringan testis tikus yang kekurangan nutrisi melalui peningkatan jumlah sel spermatogenik pada tubulus seminiferous.

\section{MATERI DAN METODE}

Penelitian ini menggunakan tikus putih jantan sebanyak 24 ekor dengan bobot 250-300 gram. Protokol penelitian telah disetujui Komisi Ethical Clearance Fakultas Kedokteran Gigi Universitas Airlangga Surabaya, No 714/ HRECC.FODM /X /2019.

\section{Perlakuan hewan coba}

Tikus dibagi secara acak menjadi empat kelompok. Pada kelompok kontrol negatif (K-), tikus tidak dipuasakan dan tidak diberi madu, sedangkan pada kelompok kontrol positif $(\mathrm{K}+)$, tikus dipuasakan selama 5 hari dan tidak diberi madu. Pada kelompok P1, dan P2 tikus dipuasakan selama 5 hari dan masing-masing diberi madu $30 \%$ dan $50 \%$ dalam air minum secara ad libitum selama 10 hari (Safitri et al., 2019). Madu yang digunakan dalam penelitian ini adalah madu monoflora yaitu madu murni kaliandra. Pada hari ke-76, semua hewan coba dikorbankan, diambil testisnya untuk dibuat preparat histologi dengan pewarnaan Hematoxylin dan Eosin (HE).

\section{Pemeriksaan sel spermatogenik}

Pemeriksaan histologi testis dilakukan dengan mikroskop cahaya (Nikon E100, perbesaran 400 kali), dilengkapi dengan kamera digital 12 megapiksel dan software Image Raster 3.0. Penghitungan sel-sel spermatogenik dilakukan secara acak pada lima tubulus seminiferous dan dihitung rata-ratanya (Ulfana et al., 2015). Sel spermatogonium berbentuk bulat dekat membran basal, inti berbentuk lonjong dengan kromatin halus dan selaput inti tipis. Spermatosit primer berukuran besar (diantara sel-sel gamet), inti heterochromatic dan terletak antara membran basal dan lumen tubulus. Spermatosit sekunder jarang terlihat dalam tubulus seminiferous karena sangat cepat membelah diri menjadi spermatid. Spermatid berbentuk bulat, lebih kecil dari spermatosit, inti bulat, pucat dan terang.

\section{Analisis data}

Data dianalisis menggunakan analisis of variance (ANOVA) dengan uji $\mathrm{F}$ pada tingkat signifikasi $(\mathrm{p}<0,05)$ dan dilanjutkan dengan uji 
jarak Duncan dengan taraf signifikasi $(\mathrm{p}<0,05)$ menggunakan SPSS versi 18 for windows.

\section{HASIL}

Tabel 1 Jumlah sel spermatogenik (spermatogonium, spermatosit dan spermatid) (rerata \pm simpangan baku) tikus (Rattus norvegicus) jantan kurang nutrisi setelah pemberian madu

\begin{tabular}{cccc}
\hline & spermatogonium & spermatosit & spermatid \\
\hline K- & $39,93 \pm 0,25^{\mathrm{c}}$ & $38,07 \pm 0,57^{\mathrm{b}}$ & $87,00 \pm 0,10^{\mathrm{b}}$ \\
$\mathrm{K}+$ & $18,63 \pm 0,99^{\mathrm{a}}$ & $24,80 \pm 0,36^{\mathrm{a}}$ & $56,33 \pm 0,82^{\mathrm{a}}$ \\
$\mathrm{P} 1$ & $19,77 \pm 0,10^{\mathrm{a}}$ & $24,67 \pm 0,42^{\mathrm{a}}$ & $59,73 \pm 0,83^{\mathrm{a}}$ \\
$\mathrm{P} 2$ & $32,67 \pm 0,27^{\mathrm{b}}$ & $34,33 \pm 0,26^{\mathrm{b}}$ & $81,22 \pm 0,10^{\mathrm{b}}$ \\
\hline
\end{tabular}

Superskrip berbeda pada kolom sama menunjukkan perbedaan signifikan ( $\mathrm{p}<0,05)$; $\mathrm{K}-$ : tikus tidak dipuasakan dan tidak diberi madu; $\mathrm{K}+$ : tikus dipuasakan lima hari dan tidak diberi madu; P1: tikus dipuasakan lima hari dan diberi madu 30\% selama 10 hari; P2: dipuasakan lima hari dan diberi madu $50 \%$ selama 10 hari; madu monoflora Kaliandra diberikan dalam air minum diberikan ad libitum
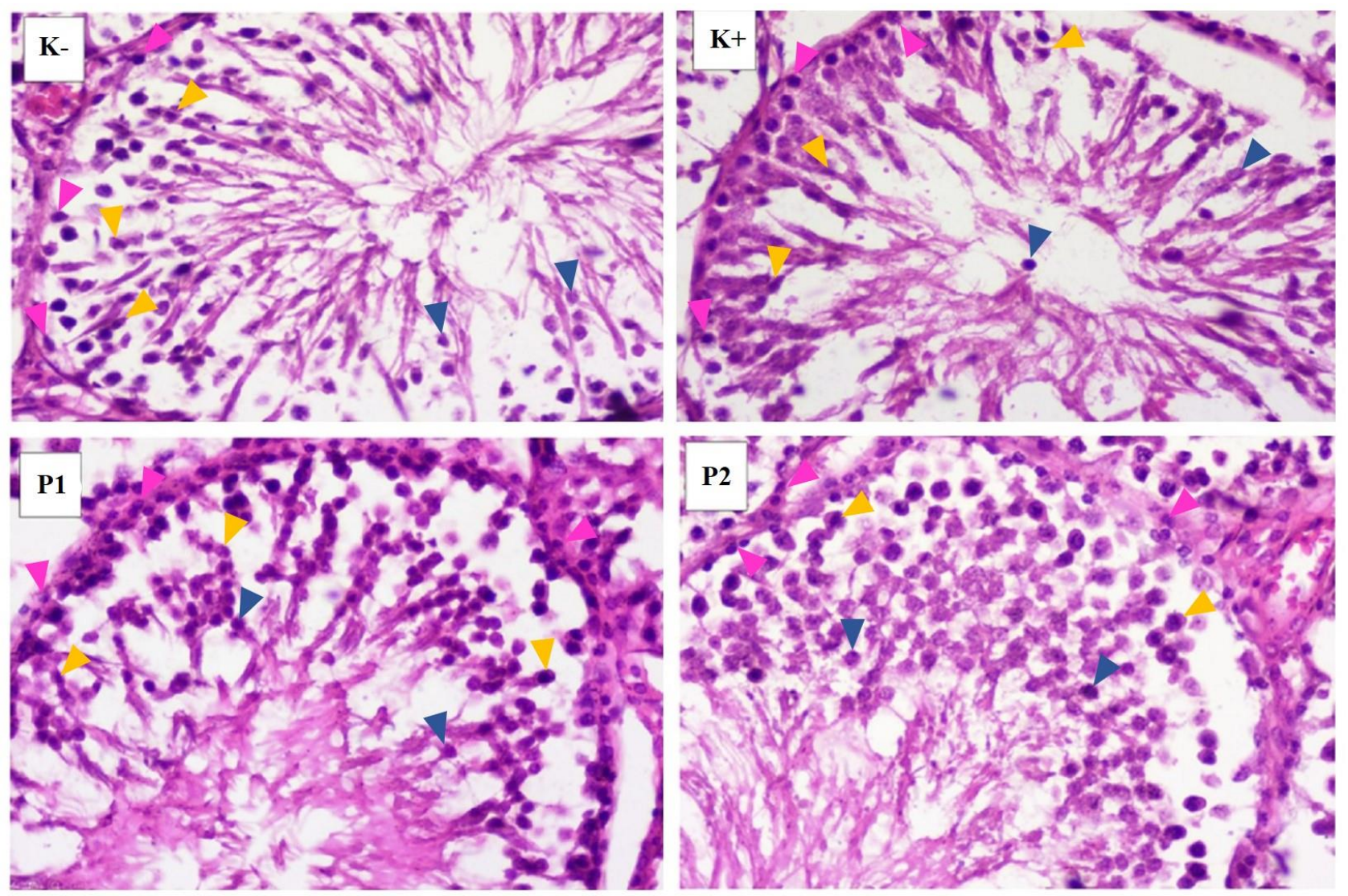

Gambar 1 Gambaran histologis tubulus seminiferus tikus (Rattus norvegicus) yang diberi perlakuan puasa dan madu; terlihat spermatogonium (kepala panah merah muda), spermatosit (kepala panah kuning), dan spermatid (kepala panah biru); $\mathrm{K}-$ : tidak dipuasakan dan tidak diberi madu, $\mathrm{K}+$ : dipuasakan lima hari dan tidak diberi madu, P1: dipuasakn lima hari dan diberi madu 30\% selama 10 hari, P2: dipuasakan lima hari dan diberi madu 50\% selama 10 hari; pewarnaan HE, pembesaran 100x (mikroskop Nikon H600L; kamera DS Fi2 300 megapixel) 
Jumlah sel spermatogonium, spermatosit dan spermatid pada tikus yang diberi asupan madu 30\% selama 10 hari (kelompok P1) tidak berbeda nyata $(p>0,05)$ dibandingkan pada tikus kelompok K+. Pemberian asupan madu 50\% (kelompok P2) selama 10 hari menyebabkan peningkatan (p <0,05) jumlah sel spermatogonium, spermatosit dan spermatid dibandingkan pada tikus kelompok K+. Pada tikus kelompok P2, jumlah sel spermatogonium lebih rendah ( $\mathrm{p}<0,05)$, sedangkan jumlah sel spermatosit dan spermatid tidak berbeda nyata dibandingkan pada tikus kelompok K- (Tabel 1 dan Gambar 1).

\section{PEMBAHASAN}

Perlakuan puasa selama lima hari (kelompok K+) menyebabkan penurunan jumlah sel spermatogonium, spermatosit dan spermatid dibandingkan tikus normal (kelompok $\mathrm{K}-$ ). Kekurangan nutrisi adalah kondisi asupan energi yang masuk tidak mencukupi kebutuhan yang dibutuhkan oleh tubuh (Stein, 2010). Kekurangan nutrisi dapat mengurangi jumlah sel sertoli sehingga memengaruhi jumlah spermatosit (Genovese et al., 2010). Selain itu, kondisi kekurangan nutrisi pada tikus dapat berdampak pada pertumbuhan spermatozoa (Toledo et al., 2011). Nutrisi juga memengaruhi morfofisiologi testis sebagai sistem endokrin, diantaranya terganggunya poros hipotalamushipofisis-gonad saat konsumsi protein dan kalori menurun. Beberapa hormon seperti LH, FSH, prolaktin, dan testosteron menjadi lebih rendah pada tikus yang mengalami malnutrisi atau kekurangan gizi (Melo et al., 2014).

Puasa yang berlebihan dapat menimbulkan stres oksidatif, yang ditandai dengan adanya peningkatan produksi radikal bebas berupa reactive oxygen species (ROS) yang dapat menyebabkan kerusakan sel (Suarsana et al, 2013). Pengoptimalan fungsi dari organ testis dan hormon rerproduksi jantan selain dipengaruhi oleh unsur genetik juga dipengaruhi oleh faktor lingkungan, seperti kualitas dan kuantitas dari sel spermatozoa (Hernawati et al, 2012). Stres oksidatif adalah fenomena yang disebabkan ketidakseimbangan ROS dalam sel dan jaringan serta ketidakmampuan tubuh untuk mendetoksifikasi ROS (Pizzino et al., 2017).
Stres oksidatif mengurangi reaksi enzimatik dan nonenzimatik pada sel Leydig sehingga menyebabkan produksi testosteron berkurang. Testis sensitif terhadap peningkatan ROS yang menyebabkan sel-sel testiskular rusak dan terjadi apoptosis (Ozbal et al., 2012). Testosteron yang berkurang akan berdampak pada penurunan steroidogenesis sehingga sekresi FSH berkurang. Penurunan jumlah sel Leydig dikarenakan kadar LH dalam tubuh yang juga menurun (Lazuardi et al.,2017).

Peran pemberian madu yang berkaitan dengan reproduksi merupakan cara meningkatkan fungsi spermatogenesis dan jumlah spermatozoa (Suprayogi et al, 2005). Namun, jumlah sel spermatogonium, spermatosit dan spermatid pada tikus yang diberi asupan madu 30\% selama 10 hari (kelompok P1) belum menunjukkan peningkatan dibandingkan kelompok $\mathrm{K}+$. Pemberian asupan madu 50\% (kelompok P2) selama 10 hari menyebabkan peningkatan ( $\mathrm{p} \quad<0,05)$ jumlah sel spermatogonium, spermatosit dan spermatid dibandingkan pada tikus kelompok $\mathrm{K}+$. Madu mengandung flavonoid sebagai komponen utama antioksidan. Madu juga mengandung gabungan senyawa yang berbeda termasuk antioksidan, asam amino, vitamin (B2, B4, B5, B6, B11, dan C), karbohidrat, protein, mineral, dan 18 asam amino bebas (Gholami et al., 2018). Antioksidan merupakan pertahanan utama melawan radikal bebas yang menyerang tubuh. Antioksidan dapat mempertahankan struktur membran sel spermatozoa terhadap adanya radikal bebas (Agarwal et al., 2005). Madu berperan mempertahankan hormon reproduksi seperti testosteron, LH dan FSH untuk meningkatkan jumlah sel spermatozoa pada tikus (Salman et al, 2013).

Pada tikus kelompok P2, jumlah sel spermatogonium masih lebih rendah dibandingkan pada tikus normal (kelompok K-), sedangkan jumlah sel spermatosit dan spermatid sudah kembali sama dengan pada tikus kelompok $\mathrm{K}-$. Hal tersebut disebabkan keraena urutan proses spermatogenesis dan perbedaan sentifitas sel-sel tersebut. Sebagaimana diketahui, proses spermatogenesis diawali dengan spermatogonia yang berada pada membran basal yang mengalami fase proliferasi, terdiri dari rangkaian pembelahan mitosis untuk 
meningkatkan jumlah sel germinal secara eksponensial, sebelum menjalani meiosis untuk ditransformasikan menjadi sel germinal haploid, spermatid dan spermatozoa (Ibtisham dan Honaramooz, 2020). Berdasarkan sensitifitasnya, sel punca spermatogonial (spermatogonium tipe A) lebih resisten daripada spermatogonia spermatogonium tipe B. Spermatogonia tipe B paling sensitif terhadap kerusakan (Abuelhija et al., 2012) karena sel-sel tersebut adalah yang paling aktif berdiferensiasi dibandingkan sel-sel lain dalam tubulus seminiferus (de Rooij, 2017), disusul kemudian spermatosit dan sel spermatid (Yadav et al., 2018).

\section{KESIMPULAN}

Pemberian madu dosis 50\% mampu meregenerasi jaringan testis tikus yang kekurangan nutrisi melalui peningkatan jumlah sel spermatogenik (spermatogonium, spermatosit, dan spermatid) pada tubulus seminiferous.

\section{UCAPAN TERIMA KASIH}

Ucapan terima kasih penulis sampaikan kepada Fakultas Kedokteran Hewan Universitas Airlangga yang telah menyediakan fasilitas penelitian. Terima kasih juga penulis ucapkan kepada dosen yang telah membantu penelitian ini Prof. Dr. Imam Mustofa, Drh. M.Si, Dr. Erma Safitri, Drh., M.Si dan Koordinator Program Studi S2 Biologi Reproduksi Dr. Rimayanti, Drh., M.Si yang telah mengawal penelitian.

\section{DAFTAR PUSTAKA}

Abuelhija M, Weng CC, Shetty G, Meistrich ML. 2012. Differences in radiation sensitivity of recovery of spermatogenesis between rat strains. Toxicol Sci. 126: 54553.

Adawiyah A, Sukandar D, Muawanah A. 2015. Aktivitas Antioksidan dan Kandungan Komponen Bioaktif Sari Buah Nammam. Jurnal Kimia VALENSI: Jurnal Penelitian dan Pengembangan Ilmu Kimia. 1: 130-6.
Agarwal A, Prabakaran SA, Said TM. 2005. Prevention of Oxidative Stress Injury to Sperm. J Androl. 26: 654-60.

Alvarez-Suarez JM, Tulipani S, Romandini S, Bertoli E, Battino M. 2010. Contribution of honey in nutrition and human health: A review. Mediterr J Nutr Metab. 3: 15-23.

Bogdanov S, Jurendic T, Sieber R, Gallmann P. 2008. Honey for Nutrition and Health: A Review. J Am Coll Nutr. 27: 677-89.

Canto A, Herrera CM. 2012. Micro-organisms behind the pollination scenes: microbial imprint on floral nectar sugar variation in a tropical plant community. Ann Bot. 110: 1173-83.

Caron E, Ciofi P, Prevot V, Bouret SG. 2012. Alteration in Neonatal Nutrition Causes Perturbations in Hypothalamic Neural Circuits Controlling Reproductive Function. J Neurosci. 32: 11486-94.

Cushnie TP, Lamb AJ. 2005. Antimicrobial Activity of Flavonoids. Int $\mathbf{J}$ Antimicrob Agents 26: 343-56.

de Rooij DG. 2017. The nature and dynamics of spermatogonial stem cells. Development 144: 3022-30.

Genovese P, Núñez ME, Pombo C, Bielli A. 2010. Undernutrition during foetal and postnatal life affects testicular structure and reduces the number of Sertoli cells in the adult rat. Reprod Domest Anim. 45: 233-6.

Gholami M, Abbaszadeh A, Khanipour Khayat Z, Anbari K, Baharvand P, Gharravi AM. 2018. Honey improves spermatogenesis and hormone secretion in testicular ischaemiareperfusion-induced injury in rats. Andrologia 50: 1-6.

Heil M. 2011. Nectar: generation, regulation and ecological functions. Trends Plant Sci. 16: 191-200.

Hernawati T, Safitri E, Utama S, Mulyati S. 2012. Penurunan angka fertilitas spermatozoa dan gambaran histopatologis tubulus seminiferus mencit (Mus Musculus) kondisi malnutrisi. Veterinaria Medika 5: 157-62.

Ibtisham F, Honaramooz A. 2020. Spermatogonial Stem Cells for In Vitro Spermatogenesis and In Vivo Restoration of Fertility. Cells 9: 745. 
Jainudeen MR, Hafez B. 2013. Reproductive Failure in Males. Dalam: Hafez, Hafez B. (Eds). Reproduction in Farm Animals, 7th Ed., Wiley-Blackwell. 279-80

Krinke GJ. 2000. The Handbook of Experimental Animals: The Laboratory Rat. Academic Press. London. 145-76.

Lazuardi DYR, Rimayanti R, Primarizky H, Sudjarwo SA, Utama S, Rachmawati K. 2017. The Effect of Blue Green Algae (Spirulina platensis) Extract in White Rat (Rattus norvegicus) Treated with Excessive Physical Exercise on Leydig Cell Number and Seminiferous Tubules Diameter. The Veterinary Medicine International Conference 2017. KnE Life Sciences. 68493.

Melo MC, Almeida FR, Caldeira-Brant AL, Parreira GG, Chiarini-Garcia H. 2014. Spermatogenesis recovery in proteinrestricted rats subjected to a normal protein diet after weaning. Reprod Fertil Dev. 26: 787-96.

Ozbal S, Ergur BU, Erbil G, Tekmen I, Bagriyanık A, Cavdar Z. 2012. The effects of $\alpha$-lipoic acid against testicular ischemiareperfusion injury in Rats. Sci World J. 489248: 1-8.

Pizzino G, Irrera N, Cucinotta M, Pallio G, Mannino F, Arcoraci V, Squadrito F, Altavilla D, Bitto A. 2017. Oxidative Stress: Harms and Benefits for Human Health. Oxid Med Cell Longev. 8416763.

Safitri E, Hariadi M. 2019. Comparison of biotechnological culture of hypoxiaconditioned rat mesenchymal stem cells with conventional in vitro culture of normoxia-conditioned rat mesenchymal stem cells for testicular failure therapy with low libido in rats. Vet World. 12: 916-24.

Safitri E, Utama S, Widiyatno TV, Sandhika W, Prasetyo RH. 2015. Auto-regeneration of mice testicle seminiferous tubules due to malnutrition based on stem cells mobilization using honey. Asian Pac. J. Reprod. 5: 31-5.

Salman TM, Alagbonsi IA, Olayaki LA, Biliaminu SA, Salahdeen HM, Olowu OA. 2013. Honey increases sperm count in male albino rats by enhancing testosterone production. Biokemistri 25: 39-44.

Sihombing DTH. 2005. Ilmu Ternak Lebah Madu. Jilid 2. Gadjah Mada University Press. Yogyakarta

Standar Nasional Indonesia. 2013. 0DGX. SNI 01-3545- 2013.

Stein AJ. 2010. Global impacts of human mineral malnutrition. Plant Soil 335: 13354.

Suarsana IN, Wresdiyati T, Suprayogi A. 2013. Respon stres oksidatif dan pemberian isoflavon terhadap aktivitas enzim superoksida dismutase dan peroksidasi lipid pada hati tikus. JITV 18: 146-52.

Suprayogi TW, Susilowati S, Triana IN. 2005. Pengaruh imunisasi sperma terhadap angka kebuntingan, kematian dini dan efek teratogenik pada tikus putih. Monograf. Universitas Airlangga.

Toledo FC, Perobelli JE, Pedrosa FP, AnselmoFranci JA, Kempinas WD. 2011. In utero protein restriction causes growth delay and alters sperm parameters in adult male rats. Reprod Biol Endocrinol. 9: 94.

Ulfana I, Darsono R, Mulyati S. 2015. Boraks mengakibatkan penurunan jumlah sel spermatogonium dan sel sertoli pada gambaran histopatologi testis tikus putih (Rattus norvegicus). Ovoozoa 4: 1-4.

Umar SH, de Queljoe E, Tendean L. 2015. Pengaruh pemberian ekstrak kulit buah manggis (Garnicinia mangostana L.) terhadap kualitas spermatozoa wistar jantan (Rattus norvegicus) yang diberi paparan suhu panas. J. e-Biomedik 3: 670-5.

Yadav SK, Pandey A, Kumar L, Devi A, Kushwaha B, Vishvkarma R, Maikhuri JP, Rajender S, Gupta G. 2018. The thermosensitive gene expression signatures of spermatogenesis. Reprod Biol Endocrinol. $16: 56$. 